\title{
In situ microbial remediation of crude oil-soaked marine sediments using zeolite carrier with a polymer coating
}

\author{
Guoqiang Zhao ${ }^{\mathrm{a}, \mathrm{b}}$, Yanqing Sheng, ${ }^{\mathrm{a}, *}$, Chuanyuan Wang ${ }^{\mathrm{a}}$, Jian Yang ${ }^{\mathrm{a}}$, Qiaoning Wang ${ }^{\mathrm{a}}$, \\ Lingxin Chen ${ }^{\mathrm{a}}$

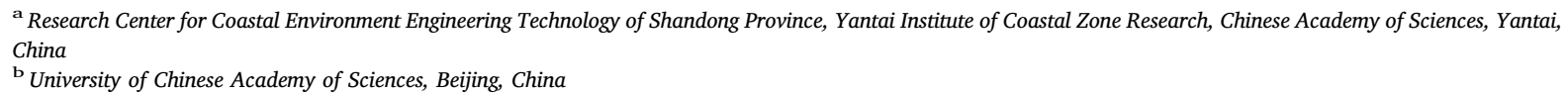

\section{A R T I C L E I N F O}

\section{Keywords:}

Poly- $\gamma$ glutamic acid

Zeolite

Bacterial agents

Oil bioremediation

Marine sediments

\begin{abstract}
A B S T R A C T
Marine oil spill pollution is an important environmental problem in the world, especially crude oil-soaked marine sediments, because they are difficult to be remediated. In this study, in situ bioremediation of oil-soaked sediment was performed in the middle of the Bohai Sea. Oil-degrading bacteria were adsorbed on powdery zeolite (PZ)/granular zeolites (GZ) surfaces and then wrapped with poly- $\gamma$ glutamic acid ( $\gamma$-PGA). Settling column and wave flume experiments were conducted to model marine conditions and to select appropriate biological reagents. The optimal conditions were as follows: the average diameter of GZ $3 \mathrm{~mm}$, mass ratio of GZ/ PZ 2:1, and concentration of $\gamma$-PGA 7\%. After bioremediation, over $50 \%$ of most oil-spilled pollutants $n$-alkanes $\left(\mathrm{C}_{12}\right.$ to $\left.\mathrm{C}_{27}\right)$ and polycyclic aromatic hydrocarbons were degraded in 70 days. This work resulted in a successful trial of in situ bioremediation of oil-soaked marine sediments.
\end{abstract}

\section{Introduction}

With the development of offshore oil exploration and ocean transportation, crude oil spills have already caused global concern and become an important source of marine environmental pollution (Guo et al., 2013). In recent years, the accidental oil spill in the Gulf of Mexico (2010) led to the release of nearly 400 million barrels of oil directly into the sea (Lin and Guo, 2015). The event is considered as the largest offshore oil spill in the world and was disastrous for the Gulf Coast environment. In China, the Dalian Port blast oil spill (2010), Penglai 19-3 oil spills in the Bohai Bay (2011), and oil pipeline blast in Qingdao (2013) caused tremendous damage to the local marine environment (Wang et al., 2015). Marine oil spills have become an important factor among those endangering the marine environment and human health (Lan et al., 2015). Marine oil spills not only damage the surrounding coastal environment, but also pose even broader danger for the entire marine system (Peterson, 2001). The migration and transformation of leaking oil in the ocean may affect marine fish hearts and eyes (Xu et al., 2016). It can also cause serious damage to fish foraging patterns and threaten the safety of other marine animals and plants (Nyankson et al., 2016). In addition to causing direct harm to the marine flora and fauna, primary or secondary pollutants generated by the oil spill may indirectly harm human health through food chain enrichment (Lei et al., 2015). Furthermore, the evaporation and dissolution of oil floating on sea surface form a dense layer of scattered ions that aggregate to form tar balls, or get adsorbed onto other particulate matter. These finally settle on the sediments, resulting in severe pollution of the seabed sediment (Yavari et al., 2015; Morales-Caselles et al., 2008; Peterson et al., 2003). Generally, spilled oil will persist in the natural environment for $>30$ years after an oil spill accident (Petkewich, 2002). Under the turbulent mixing of ocean currents and waves, the oil or oil oxidation products sinking into the sea can return to the sea surface, causing secondary pollution (Ranjbar et al., 2014).

For remediation of oil spill tar balls pollution, a variety of advanced clean-up technologies have been applied. Special abrasive paper can be used to clean up the oil spill (Shi et al., 2015), and the oil can be collected by oil skimmers or simply be burnt off (Song et al., 2014). Chemical sorbents and dispersants are also common methods for treating spilled oil (Lim et al., 2016). However, these kinds of physical and chemical methods can be harmful to the environment and aquatic life (Schaum et al., 2010; Kujawinski et al., 2011), and most of these clean-up methods can only be applied to remedy surface oil spills. Compared to physical and chemical techniques, bioremediation is a well-described technology for the remediation of oil spill pollution (Pavitran et al., 2006; Dua et al., 2002; Okoh and Trejo-Hernandez, 2006; Fernandez-Luqueno et al., 2011). Although this method can be

\footnotetext{
* Corresponding author.

E-mail address: yqsheng@yic.ac.cn (Y. Sheng).
} 
applied to remedy floating oil on the seawater or on the beach and in soils, it has limitations for the remediation of oil-soaked sediments on the ocean bottom under deep water. This is because it is difficult to spread bioremediation remedy agents (RAs) on the contaminated marine sediments. Therefore, few technologies have been reported for the remediation of oil-polluted sediment in deep sea areas. Although oil dispersants have been used to remedy deep sea oil pollution, both options and efficacy suffer from great uncertainty (Carriger and Barron, 2011).

Application of functional microorganisms like bacteria is a useful technique for oil pollution remediation. Previous studies reported that the bacterial genus Bacillus spp. has high efficacy for crude oil biodegradation (Tao et al., 2017; Chettri et al., 2016). Poly- $\gamma$ glutamic acid $(\gamma$-PGA) and chitosan are natural biopolymers that are widely used as wrapping agents (Shi et al., 2016), flocculants, or bioremediation agents in environmental engineering (Wang et al., 2014) because of their biodegradability (Liu et al., 2015; Matsusaki et al., 2002). Zeolite is a natural and economic material used for pollution control because it has high specific surface area, medium $\mathrm{pH}$ and no secondary pollution (Shi et al., 2009; Javed et al., 2016; Castaldi et al., 2005; Kumpiene et al., 2008). If the oil-degrading bacteria could be loaded onto powdery zeolite (PZ) or granular zeolites (GZ) and then wrapped with $\gamma$ PGA or chitosan, they could be distributed on the bottom without the bacteria being washed away by currents to realize sediment bioremediation.

The goal of this work was to perform in situ bioremediation engineering of oil-soaked marine sediments using the combination of oildegrading bacteria (Bacillus spp., patent protection), bacterial adsorbent (zeolite), and wrapping agents ( $\gamma$-PGA or chitosan). The objectives were 1 ) to find and evaluate a suitable microorganism wrapping agent to decrease the loss of effective (living) bacteria during the delivery process, and 2) to investigate the efficiency of petroleum hydrocarbon degradation after bioremediation. In this work, the use of a feasible technology was explored and new thought provided about the remediation of oil-soaked marine sediments.

\section{Method and materials}

\subsection{Materials preparation}

In order to put liquid petroleum degrading bacteria (microbial inoculum) onto the sea floor efficiently, different absorbing and wrapping agents were selected in this study. Microporous zeolites (GZ and PZ) were used as the adsorbents and carriers for the oil-degrading bacteria. With zeolite, the bacteria could be fully adsorbed and the wrapping agents loaded, which were purchased from a local market. The GZ and PZ used in the present study was clinoptilolite, which was natural zeolites with atypical unit cell formula $\mathrm{Na}_{6}\left[\left(\mathrm{AlO}_{2}\right)_{6}\left(\mathrm{SiO}_{2}\right)_{30}\right] \cdot 24 \mathrm{H}_{2} \mathrm{O}$. The clinoptilolite has a characteristic tubular morphology that shows an open reticular structure of easy access, formed by open channels of 8-10 membered rings (Paola et al., 2018). The different GZ diameters tested were $1 \mathrm{~mm}(\mathrm{~mm}), 3 \mathrm{~mm}, 5 \mathrm{~mm}$, and $\geq 7 \mathrm{~mm}$. The average diameter of the PZ was $\sim 30 \mu \mathrm{m}$, and its specific surface area was 230-320 $\mathrm{m}^{2} \mathrm{~g}^{-1}$. The bacterial adsorption rates of different zeolite materials (GZ and PZ) were determined after being soaked for $30 \mathrm{~min}$ in microbial inoculum. Potential wrapping agents used in this study were chitosan and $\gamma$-PGA. Chitosan (content $>90 \%$, white powder crystalloid, molecular weight of $c a .1450 \mathrm{kDa}$ ) was purchased from Jinan Tianben Biological Technology Co., Ltd., Jinan, China. Chitosan was dissolved in $2 \%$ (volume ratio) acetic acid solution prior to use. The $\gamma$ PGA (content $>99 \%$, agricultural level, molecular mass 700-1100 kDa, white, granulate, free-flow particle crystalloid) was purchased from Freda Biotechnology Co., Ltd., Shandong, China. The oil-degrading bacteria (in solution) were selected and cultured from oil-polluted sludge; the dominant bacterial genus was Bacillus spp. (patent protection, preserved in China General Microbiological Culture Collection Center, Beijing, China). The initial concentration of the oil-degrading bacteria was $1 \times 10^{9} \mathrm{CFU} \mathrm{mL}^{-1}$. Mass production of the absorbent (mixture of GZ and PZ) and the wrapping ( $\gamma$-PGA) agent was authorized to a local biological technology company.

\subsection{Experimental design}

\subsubsection{Optimal GZ diameter and mix ratio investigation}

In order to ensure a sufficient count of effective (living) bacteria in zeolite, three groups were set with GZ diameters of $3 \mathrm{~mm}, 5 \mathrm{~mm}$, or $7 \mathrm{~mm}$. Each group had six parallel variations with different mass ratios of GZ to PZ, which were set as $0.8,1.2,1.6,2.0,2.4$, and 2.8. The same concentration of a wrapping agent (chitosan or $\gamma$-PGA) was added to the different ratio variants prior to testing. The concentration of chitosan was set as $1 \%$ or $2 \%$ (dissolved in $2 \%$ acetic acid solution). The concentration of $\gamma$-PGA was set as $1 \%, 3 \%, 7 \%$, or $14 \%$ (dissolved in deionized water). The $\mathrm{pH}$ values of the different concentrations of chitosan and $\gamma$-PGA were measured prior to use. Because the microbial inoculum is colorless and transparent, red dye was applied to trace the migration path of the oil-degrading bacteria prior to determination of the bacterial concentration.

\subsubsection{Modeling test procedure}

Based on the results of Section 2.2.1, GZ and PZ were mixed in a beaker (with optimal mass ratio); then, microbial inoculum was added to the beaker. After $30 \mathrm{~min}$ of agitation for adsorption (saturated adsorption rate was $22 \% \mathrm{wt} / \mathrm{wt}$, established in a preliminary experiment), superfluous microbial inoculum solution was discarded. Next, either chitosan or $\gamma$-PGA (at optimal concentration) was added to the beaker, with agitation for $\sim 5 \mathrm{~min}$ to produce flocculation block. When the block inclusions were in the process of settlement (settling column, Fig. 1), they first maintained a polymeric block at the top of the settling
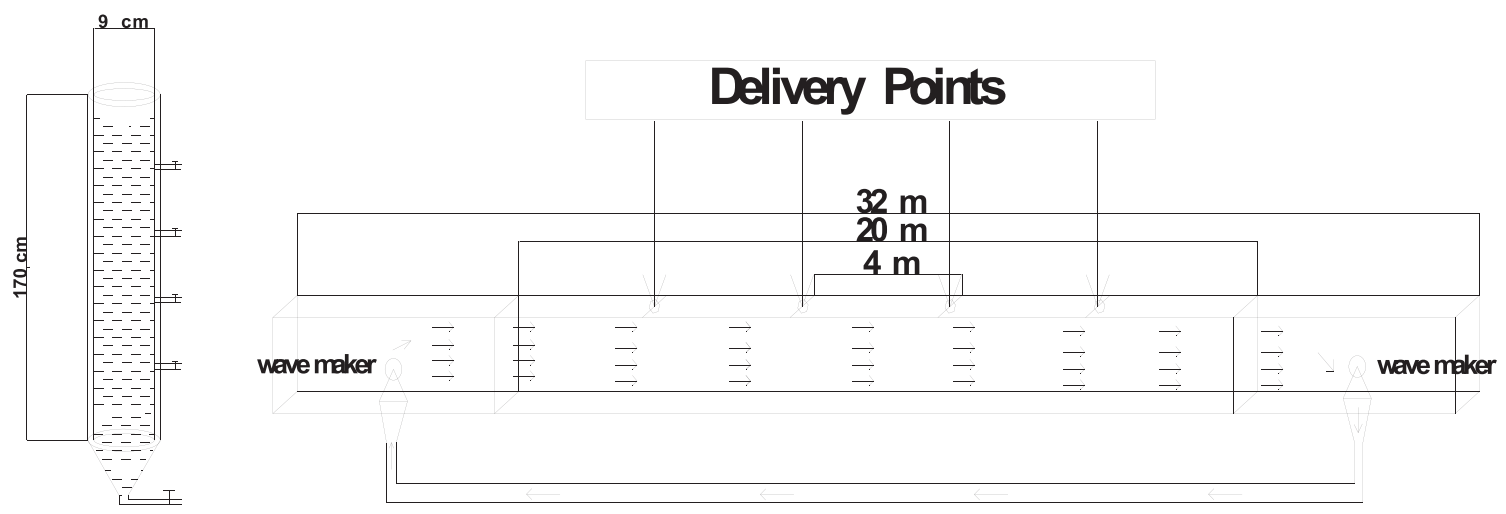

Fig. 1. Diagrammatic sketches of settling column (left) and wave flume (right). 
column, and then became grainy near the bottom of the settling column. Maintaining the polymeric state protected the bacteria from water erosion. And RAs were dispersed into small particles in order to allow more bacteria to spread on the oil-polluted sediment surfaces. Only in this state, the loss rate of bacteria was kept to a minimum. As a result, the best delivery efficiency could be achieved (Brown et al., 2013). At the same time, the greater the carrier sedimentation velocity in the water, the shorter the time they spent in the water, with the result that there would be less flushing effect on the carriers by water.

\subsection{Experimental instrument}

In order to trace the migration path of oil-degrading bacteria in flowing seawater, a settling column and a wave flume were applied in this test. All modeling tests were conducted in the settling column $(9 \mathrm{~cm}$ in diameter, $170 \mathrm{~cm}$ in depth) and the wave flume $(3200 \mathrm{~cm}$ in length, $150 \mathrm{~cm}$ in depth, and $80 \mathrm{~cm}$ in width), respectively. The clean seawater in the model test was collected from a coastal trestle bridge in Yantai $\left(\sim 200 \mathrm{~m}\right.$ away from the beach, $\left.37^{\circ} 2929.98 \mathrm{~N}, 121^{\circ} 2718.72 \mathrm{E}\right)$. The depth of the seawater in the settling column was $170 \mathrm{~cm}$. During the experiment, seawater samples were collected from the bottom valve installed in the settling column (Fig. 1, left). The settling column was used to investigate the vertical settling process of the RAs. The wave flume was used to investigate the horizontal migration of the RAs. The stability of the reciprocating flow and water flow rate or velocity $\left(1 \mathrm{~m} \mathrm{~s}^{-1}\right)$, was strictly controlled during tests. The direction of water flow was constant. The RAs were put into the wave flume from four delivery points (Fig. 1, right).

During the settling column experiment, the optimal proportion between PZ and GZ, and polymer concentration were investigated through the RAs settlement state and the concentration of oil-degrading bacteria at different depths. The RAs settlement state was determined through the following red dye tracer experiment. For the wave flume experiment, RAs were produced based on the results of the settling column experiment (same composition and proportion). The wave flume experiment was conducted in a water column with constant flow, which was to simulate the ocean bottom water currents (Fig. 1, right). The detailed settlement process was designed in the following steps: 1) a certain amount of PZ and GZ (different mass ratios) were mixed and dyed with red dye (the amount of red dye added was determined according to the saturated moisture content of the PZ and GZ); 2) a certain amount of the wrapping agent (chitosan or $\gamma$-PGA at several concentrations) was added to form red lumps; 3 ) these red lumps were thrown into the settling column and wave flume (Figs. 1 and 4) the performance of the optimal carriers was determined according to the decentralized state, the drift path of red dye (bacterial tracer), and the settling velocity.

For the wave flume test, the RAs used were the same as the optimized RAs (GZ/PZ, 2; GZ diameter, $3 \mathrm{~mm}$; 7\% $\gamma$-PGA) in the settling column experiment, except that the volume of the lumps was expanded ten times (from $2 \mathrm{~cm} \times 2 \mathrm{~cm} \times 2 \mathrm{~cm}$ to $20 \mathrm{~cm} \times 20 \mathrm{~cm} \times 20 \mathrm{~cm}$ ). Four sampling points were set at vertical intervals of $50 \mathrm{~cm}$ at each delivery point. A total of six sampling points (at intervals of $100 \mathrm{~cm}$ ) at two levels (wave flume bottom and above $50 \mathrm{~cm}$ ) were set in the downstream direction of the remedial agent landing point. After releasing the RAs, water samples were immediately collected from four vertical sampling points, and water samples were collected from the six transverse sample points after $30 \mathrm{~min}$. The water current velocity in the wave flume was set as $1 \mathrm{~m} \mathrm{~s}^{-1}$ to model the actual marine water flow condition.

\subsection{In situ engineering or field test}

The oil spill area is located in the middle of the Bohai Sea (Fig. 2). The total area of the field test site was $900 \mathrm{~m} \times 850 \mathrm{~m}$. A total of 370 ton of RAs was produced using the results of the modeling test. The

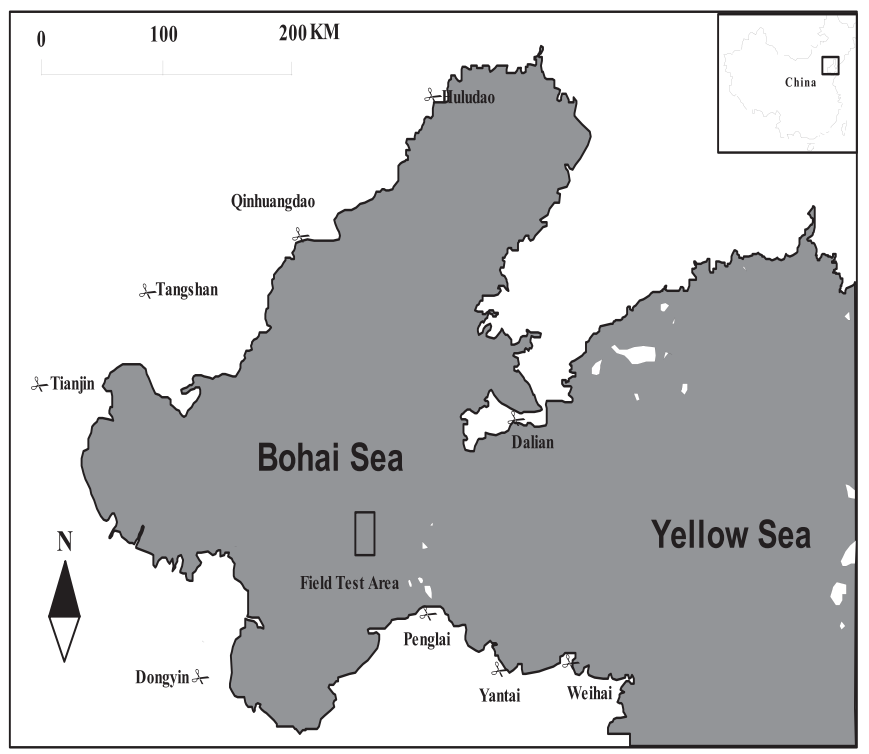

Fig. 2. Detailed location of the field engineering.

method involved the loading of oil-degrading bacteria onto the carriers (PZ and GZ) by $\gamma$-PGA. The fresh RAs were individually packed in $\sim 5 \mathrm{~kg}$ degradable gunny-bags; then, the bags were thrown into the water directly. The principal objective of this method was to ensure that a certain amount of the bacteria penetrated the overlying seawater and reached the polluted sediments.

\subsection{Analysis and evaluation}

The concentrations determination of the crude oil-degrading bacteria in samples was based on the dilution plate-count procedure (Woolfrey and Enright, 1990). Triplicates were carried out in all modeling tests. Crude oil content of the sediments was determined both before and after in situ remediation engineering. Sediment samples were collected by a stainless steel grab sampler, then dried at $60^{\circ} \mathrm{C}$, and separated to remove large particles and debris. The sediment samples were weighed and spiked with surrogate recovery standards (terphenyl$\mathrm{d} 14)$ and then Soxhlet-extracted for $72 \mathrm{~h}$. The $n$-alkanes $\left(\mathrm{C}_{12}\right.$ to $\left.\mathrm{C}_{27}\right)$ and polycyclic aromatic hydrocarbon (PAHs) were obtained by successive elution with n-hexane, toluene, and chloroform/methanol. An aliquot of $1 \mathrm{~mL}$ of each extract was subjected to Gas Chromatography-Mass Spectrometer (GC-MS) analysis. Individual $n$-alkanes and PAHs were quantified based on the retention time and $m / z$ ratio of authentic $n$ alkanes and mixed PAHs standard.

The concentrations of $n$-alkanes and PAHs were measured using the external calibration standards (Sigma code: 46827-U, 47543-U, Supelco, purchased from Sigma-Aldrich). For PAHs analysis, five surrogate standards (naphthalene-d8, phenanthrene-d10, dibenzothiophene-d10, fluoranthene-d10, and pyrene-d10) were added to all samples to monitor matrix effects. The average recoveries of the surrogate standards varied from $81.6 \%$ to $92 \%$. Blanks were run for the entire procedure including extraction, solvent concentration and purification. All concentration values were blank- and recovery- corrected. In addition, the detection limit ranged from $0.15 \mathrm{ng} \mathrm{g}^{-1}$ to $0.7 \mathrm{ng} \mathrm{g}^{-1}$ (dry weight). Triplicates were analyzed for all samples, and the results are expressed as their average \pm SD. The relative standard deviation (RSD) of the measurements is $\leq 5 \%$. 
Table 1

Bacterial adsorption rates of GZ and PZ.

\begin{tabular}{|c|c|c|c|c|c|}
\hline & GZ & & & & $\mathrm{PZ}$ \\
\hline Zeolite diameters & $1 \mathrm{~mm}$ & $3 \mathrm{~mm}$ & $5 \mathrm{~mm}$ & $7 \mathrm{~mm}$ & $30 \mu \mathrm{m}$ \\
\hline Adsorption rates & $66 \%$ & $59 \%$ & $18 \%$ & $12 \%$ & $74 \%$ \\
\hline
\end{tabular}

\section{Results and discussion}

\subsection{Materials selection and reagent production}

The bacterial adsorption rates of GZ and PZ are listed in Table 1. It can be seen that the bacterial adsorption rates decreased with GZ diameters increase. Because PZ is porous and has high specific surface area $\left(230-320 \mathrm{~m}^{2} \mathrm{~g}^{-1}\right)$, and because most bacteria were adsorbed on the surface, use of the $\mathrm{PZ}$ resulted in the highest bacterial adsorption rate.

Fig. 3 illustrated the SEM photographs of GZ, before (left) and after bacterial adsorption (right). The surface before bacterial adsorption was smooth. After bacterial adsorption (right), the surface became coarse, with many small pellets (bacteria) adhered to the surface. This result indicated that lots of bacteria were absorbed in the GZ. It dues to the GZ had reticular and porous structure. Consequently the GZ can be used as an adsorbent for bacteria.

The variations in the $\mathrm{pH}$ of different ratios of zeolite (PZ and GZ) and wrapping agents are shown in Table 2. During the agglomeration process after addition of the chitosan solution, the stickiness of formed zeolite lumps in the beaker gradually decreased after agitation and mixture. Notably, the agitation and mixture process was accompanied by the release of bubbles. The results indicated that the chitosan solution reacted with substances in the zeolite and released $\mathrm{CO}_{2}$ gas. In this work, chitosan solution was deployed in $2 \%$ acetic acid solution. Generally, zeolites contain a small quantity of calcium carbonate (impurity). This could react with the acetic acid and produce carbon dioxide $\left(\mathrm{CO}_{2}\right.$ bubbles). Furthermore, the viscosity of the chitosan decreased after the reaction because of an increase in the $\mathrm{pH}$ (Suh and Matthew, 2000). However, the pH was still low (3.9-4.7, Table 2) after the above reaction because of the remaining acetic acid. For the wrapping agent $(\gamma$-PGA), the $\mathrm{pH}$ was $6.6-7.8$, near neutral values. Therefore the $\gamma$-PGA was selected as the wrapping agent owing to the optimum survival $\mathrm{pH}$ range of the oil-degrading bacteria varied from neutral to slightly alkaline (6-8) (Luo et al., 2013). The detailed results are shown in Table 2.

\subsection{Settling column experiment}

\subsubsection{Optimal $G Z$ diameter and ratio between $P Z$ and $G Z$}

In preliminary experiments, saturated water content in $\mathrm{GZ}$ and $\mathrm{PZ}$ ( $\sim 200$ mesh) were determined, which were $20 \%$ and $23 \%$, respectively.
Table 2

The $\mathrm{pH}$ of zeolite, $\gamma$-PGA, and chitosan.

\begin{tabular}{llllllll}
\hline Zeolite & $\mathrm{pH}$ & $\gamma$-PGA & $\mathrm{pH}$ & $\gamma$-PGA & $\mathrm{pH}$ & Chitosan & $\mathrm{pH}$ \\
\hline $\mathrm{GZ}$ & 7.50 & $1 \% \gamma$-PGA & 6.74 & $7 \% \gamma$-PGA & 6.62 & $1 \%$ chitosan & 4.69 \\
$\mathrm{PZ}$ & 7.80 & $3 \% \gamma$-PGA & 6.58 & $14 \% \gamma$-PGA & 6.42 & $2 \%$ chitosan & 3.94 \\
\hline
\end{tabular}

Because the oil-degrading microbial inoculum were in aqueous state, the maximum amount of microbial inoculum loaded onto the zeolites could be calculated through the saturated moisture content of the zeolites (Eq. (1)).

$\mathrm{C}=\mathrm{C}_{0} *\left(\mathrm{~S}_{1} * \mathrm{M}_{1}+\mathrm{S}_{2} * \mathrm{M}_{2}\right) / \rho$

In Eq. (1), (C) represented the number of oil-degrading bacteria loaded onto the RAs (CFU); $\left(\mathrm{C}_{0}\right)$ was the initial concentration of the oildecomposing microbial inoculum $(\mathrm{CFU} / \mathrm{mL}) ;\left(\mathrm{S}_{1}\right)$ and $\left(\mathrm{S}_{2}\right)$ were the saturated moisture content of $\mathrm{GZ}$ and $\mathrm{PZ}$ respectively (\%); $\left(\mathrm{M}_{1}\right)$ and $\left(\mathrm{M}_{2}\right)$ represented the mass of GZ and PZ in the RAs respectively (g); $(\rho)$ was the density of oil-degrading microbial inoculum (regarded as the density of water: $1 \mathrm{~g} / \mathrm{mL}$ ). Although the PZ could absorb more oil-degrading bacteria than the GZ do, the PZ could not be used alone as the bacteria carrier with $\gamma$-PGA addition because the lumps formed by PZ mixed with $\gamma$-PGA could not be dispersed during the setting process in water. Consequently, the most of bacteria adsorbed in the PZ lumps could not be released from lumps to the oil-soaked sediment surface at the bottom. Similarly, the GZ also could not be used alone as the carrier because it could not absorb enough viable bacteria with its limited surface. And the oil-degrading bacteria absorbed in the GZ could be easily washed away by strong water currents because the GZ mixed with $\gamma$-PGA could not formed sticky lumps (inattentive). So the $\gamma$-PGA coated on the surface of GZ could not protect the adsorbed bacteria loss. As a consequence, a mixture of PZ and GZ (with the adhesion by $\gamma$-PGA) should be selected as the optimal carrier. In Fig. 4, for the different carrier mixtures, the average settling velocities increased with the mass ratio of GZ/PZ (with different diameters of GZ).

Overall, when the mass ratio of the GZ/PZ was greater than "2", the settling velocity of $3 \mathrm{~mm}$ and $5 \mathrm{~mm}$ GZ first began to decrease, and then became constant with the average velocity $0.333 \mathrm{~m} \mathrm{~s}^{-1} \pm 0.013 \mathrm{~m} \mathrm{~s}^{-1}$ and $0.319 \mathrm{~m} \mathrm{~s}^{-1} \pm 0.013 \mathrm{~m} \mathrm{~s}^{-1}$ respectively (Fig. 4). However, the $7 \mathrm{~mm}$ GZ settling velocity slightly increased and then stabilized at $0.325 \mathrm{~m} \mathrm{~s}^{-1} \pm 0.012 \mathrm{~m} \mathrm{~s}^{-1}$ (Fig. 4). Previous research reported that the settling velocity of GZ of the same nature, in water, is the product of the GZ density distribution in a sample and the GZ geometric properties (Song et al., 2014). In this work, the settling velocity might increase because of the higher density of the lumps (denser than before), as the mass ratios of the zeolite (lumps) did not change significantly. However, if the mass ratio increased to a certain degree $(>2)$, the effect of adhesion of $\gamma$-PGA would be restrained, and then zeolite lumps began
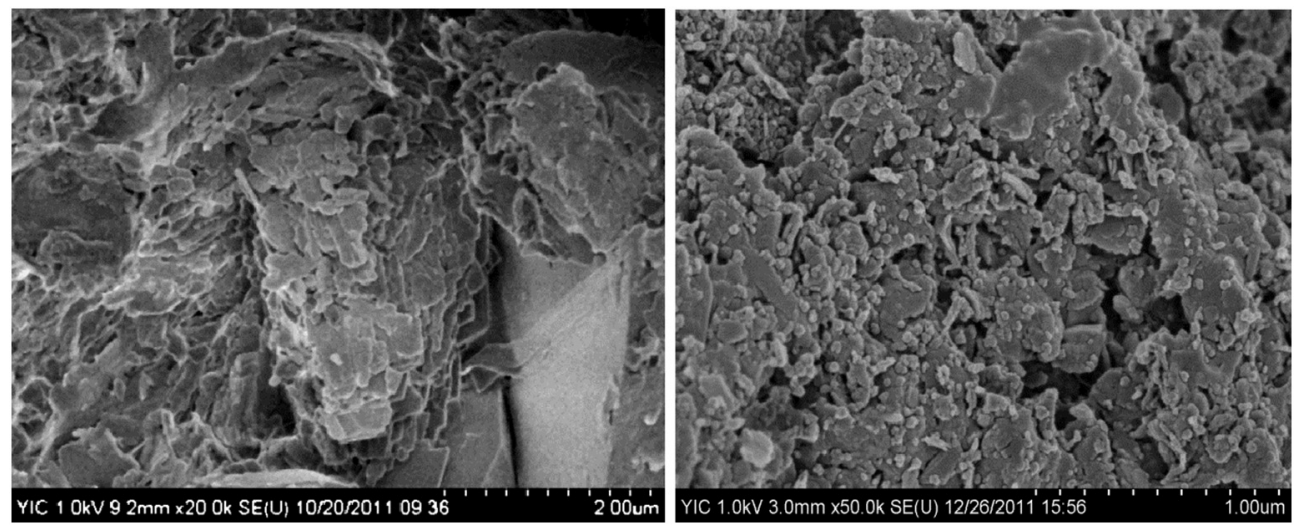

Fig. 3. SEM photographs of GZ: before (left) and after (right) bacteria adsorption. 


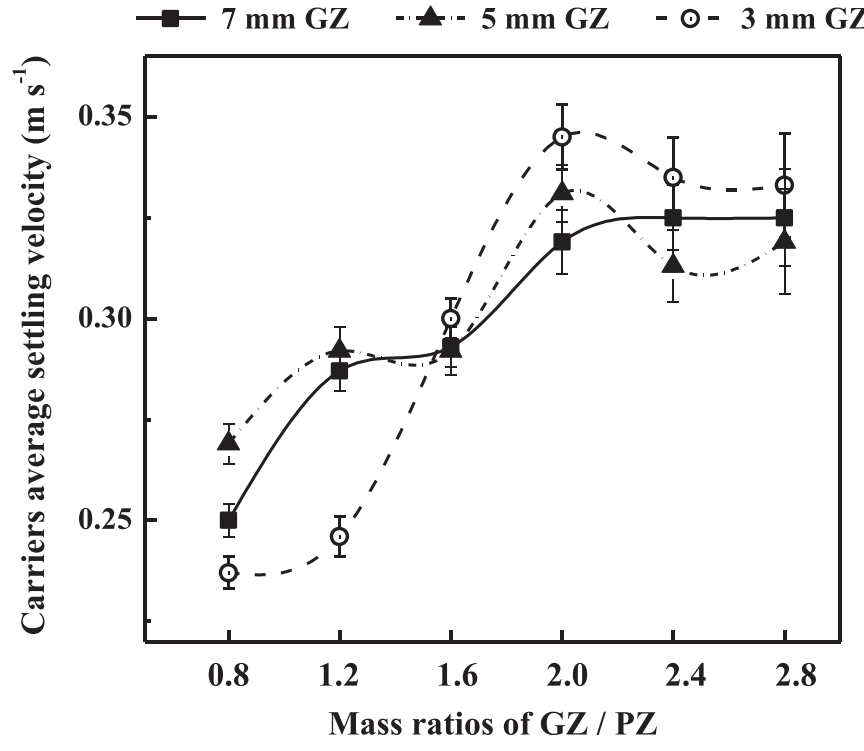

Fig. 4. Variation of average settling velocities for different carrier mixtures.

dispersed and the amount of PZ would reach its maximum. Therefore, the density of RAs reached saturation, and the maximum value of the settling velocity was achieved.

At the same time, the GZ diameter and the added amount influenced the adhesiveness of the carriers (zeolite lumps): with the larger diameter and more amount of GZ addition, zeolite lumps began to disperse when the ratio greater than " 2 ", so the lower adhesiveness achieved. It could possibly explain that the dispersion degrees of zeolite lumps were different when the mass ratio beyond 2. Especially, the dispersion degree of the $5 \mathrm{~mm}$ GZ lumps was greater than the $3 \mathrm{~mm}$ GZ lumps (partially dispersion, Table 3), which leaded to the density of $5 \mathrm{~mm} \mathrm{GZ}$ lumps became less than the $3 \mathrm{~mm}$ GZ lumps with the setting velocity steeper declines. However, the $7 \mathrm{~mm}$ GZ lump gradually began disperse completely with its lump density slightly increase owing to the $7 \mathrm{~mm}$ GZ density was slightly larger than its lumps with the mass ratio equaling 2 (Fig. 4 and Table 3 ).

The change in water color can reflect the escape path of the bacteria. In Table 3 , carrier states changed from polymerization to dispersion gradually during the settlement process with increase in the ratios of GZ/PZ. Overall, the lumps with low ratios (0.8-1.6) were not dispersed during the settlement process. However the lumps began to disperse as the ratio approximately equaled 2 . In the present study, the main objective was to send oil-degrading bacteria to the polluted sediment surface, and therefore, the ideal state was that the lump could spread out completely near the sediment to release the bacteria. If the number of GZ was excessive, the degrading bacteria would be flushed out from the zeolite surfaces during settlement. Such condition would not be conducive for delivering the oil-degrading bacteria. In summary, the optimal mass ratio of GZ/PZ should be $\sim 2$. Additionally, the setting velocity of zeolite lumps (bacteria carriers) was high in water at the ratio $(\sim 2)$, which could minimize the settling time of zeolite lumps and reduce the degree of the oil-degrading bacteria eroded by water.

Table 3

Carrier dispersed states with different GZ/PZ values.

\begin{tabular}{lll}
\hline Ratios of GZ/PZ & Dispersed state & Water color \\
\hline 0.8 & No dispersion & Slight red \\
1.2 & No dispersion & Slight red \\
1.6 & Slightly partial dispersion & Moderately partial red \\
2.0 & Partial dispersion & Partial red \\
2.4 & Complete dispersion & Complete red \\
2.8 & Complete dispersion & Complete red \\
\hline
\end{tabular}

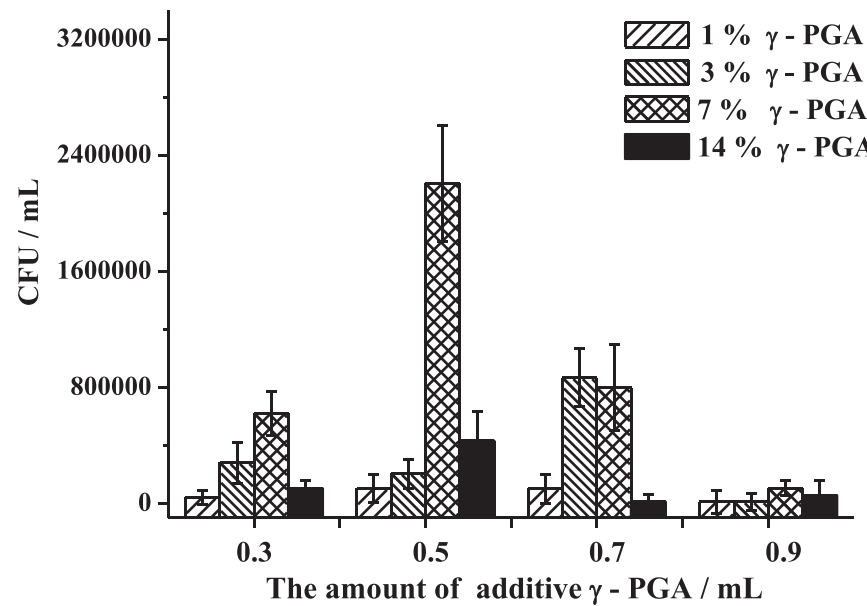

Fig. 5. Variations concentrations at the bottom of the settling column in relation to $\gamma$-PGA amount and concentration.

\subsubsection{Determination of $\gamma$-PGA optimal dosage}

Based on the above experimental results, the optimal mass ratio of $\mathrm{GZ} / \mathrm{PZ}$ and GZ diameter (GZ/PZ was 2 , GZ diameter was $3 \mathrm{~mm}$ ) were selected to perform the oil-degrading bacteria release experiment in the setting column. Water samples were collected from the valves installed on the side wall of the settlement column after the RAs delivery (Fig. 1, left). The relationships between the concentrations of oil-degrading bacteria and $\gamma$-PGA dosage at different depth in the settling column were illustrated in Fig. 5. The optimal dosage and concentration of $\gamma$ PGA were determined according to the final number of the oil-degrading bacteria at the setting column bottom.

Totally, the number of oil-degrading bacteria increased with the concentrations of $\gamma$-PGA increase when its concentration was lower than $7 \%$. However, it significantly declined when the $\gamma$-PGA concentration was higher than $7 \%$. This phenomenon could possibly be explained that different concentration of $\gamma$-PGA has different stickiness. The low concentration of $\gamma$-PGA $(1 \%, 3 \%)$ has relatively low viscosity that could not protect the bacteria from being washed out. However, if the concentration of $\gamma$-PGA reached to $14 \%$, the high stickiness would make a lot of bacteria stick to the GZ and PZ, resulting in most oildegrading bacteria could not be released from the RAs (Wang et al., 2004).

Additionally, the concentration of the bacteria detected at the bottom generally increased first and then decreased as the amount of $\gamma$ PGA increased for the same concentration of $\gamma$-PGA. This was possibly because the amount of $\gamma$-PGA was too low to keep enough bacteria on the carrier surface during the settlement process, while a high dosage of $\gamma$-PGA could result in gumminess. However, excessive $\gamma$-PGA could produce a thick wrapping film that hindered the release of the oil-degrading bacteria (difficult to wash out) during settling, resulting in low bacterial concentrations at the bottom. Therefore, the results indicated that the $\gamma$-PGA concentration of $7 \%(0.5 \mathrm{~mL}$ dosage $)$ was the optimal throwing condition.

\subsection{Wave flume experiment}

The amounts of bacteria present in the water samples are illustrated in Fig. 6. The results showed that the concentration of oil-degrading bacteria decreased with the water depth increase during the sinking process (Fig. 6, left). The phenomenon may relate to the bacteria on the lump surfaces being flushed out immediately after they were thrown. This component resulted in the highest bacteria concentration in upper water layer. With sinking, the lumps tended to be stable; the bacterial concentration kept similarity values close to the bottom. Of course, most of the bacteria were still inside the lumps, which were less affected 

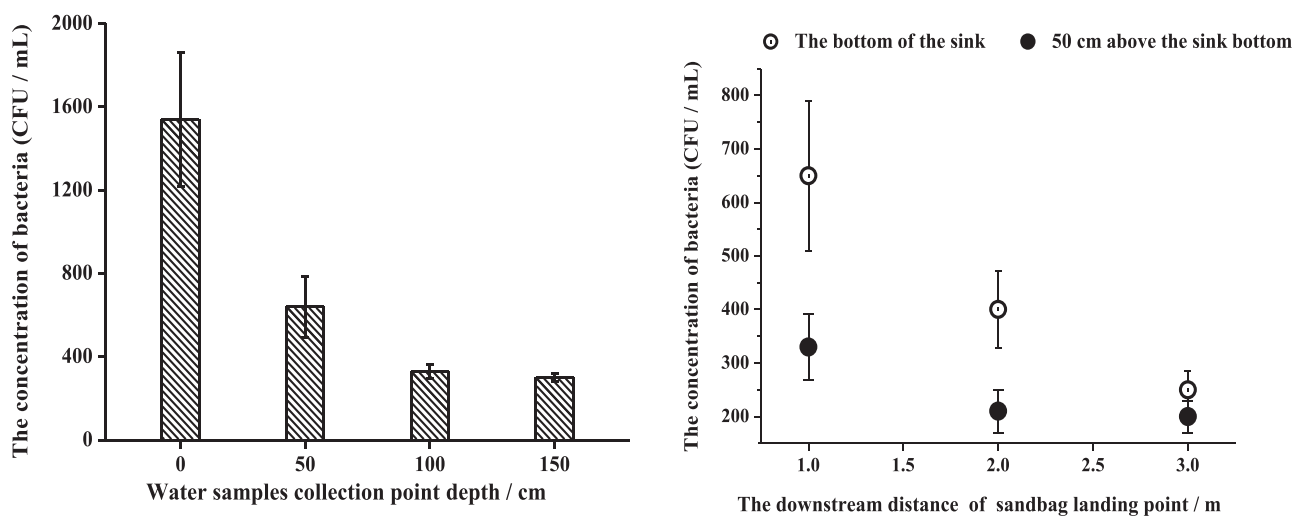

Fig. 6. Concentrations of bacteria after vertical and horizontal movement in water.

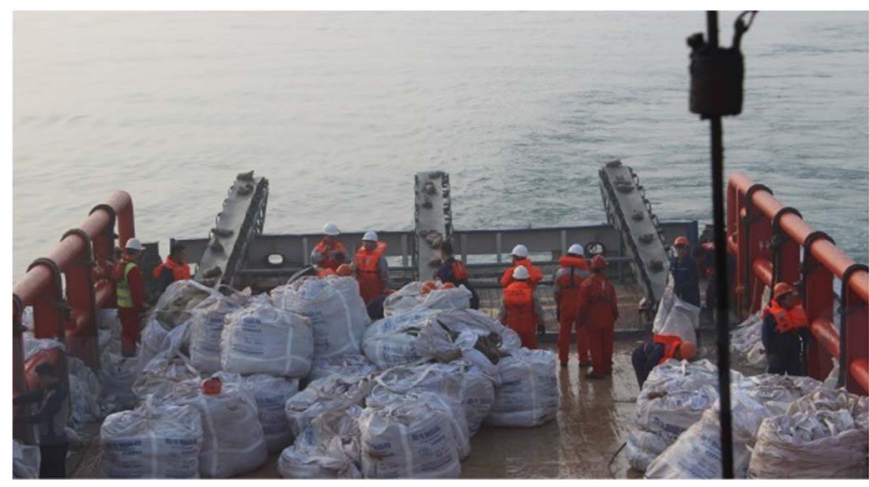

Fig. 7. Distribution of RAs during field remediation.

by interface water erosion under $\gamma$-PGA protection. Regarding horizontal variation, the bacterial concentration decreased with horizontal distance along the direction of the water current. When the distance reached approximately $3 \mathrm{~m}$ from the throwing point, the bacterial concentration began to be stable (Fig. 6). This result indicates that the valid horizontal distance to achieve stability in the concentration of bacteria is $\sim 3 \mathrm{~m}$ when the water current velocity is $1 \mathrm{~m} \mathrm{~s}^{-1}$ (close to the actual current velocity in the Bohai Sea).

\subsection{Field tests of oil-polluted sediment remediation}

The remediated region covered an area of $0.76 \mathrm{~km}^{2}$, above which 370 ton of RA was uniformly thrown onto the ocean floor containing oil-polluted sediments via $5 \mathrm{~kg}$ degradable mesh bags. The distance between the mesh bags was $\sim 3 \mathrm{~m}$, which was controlled by the trestle distance on the deck and the speed of the cargo vessel (Fig. 7). After 70 days, sediment samples were collected in the polluted area using a grab sampler, and the oil content was determined. The detailed variation of concentration is listed in Table 4. It can be seen that the relative degradation values of the $n$-alkanes were $>50 \%$ for most stations that received treatment. At different sampling sites, the concentration of $n$ alkanes ranged from $1777 \pm 71.7 \mu \mathrm{gg}^{-1}$ to $3761 \pm 135.4 \mu \mathrm{g} \mathrm{g}^{-1}$ dry sediment, before bioremediation. Seventy days after treatment, its concentrations ranged from $1087 \pm 21.7 \mu \mathrm{gg}^{-1}$ to $1393 \pm 55.8 \mu \mathrm{g} \mathrm{g}^{-1}$ dry sediment. At the same sampling sites after treatment, the removal rates ranged from $34 \%$ to $64 \%$, with an average removal rate of $52 \%$.

Regarding the variation of PAHs at different sampling sites, their concentration ranged from $103 \pm 2.1 \mu \mathrm{gg}{ }^{-1}$ to $273 \pm 13.7 \mu \mathrm{gg}^{-1}$ dry sediment before treatment with RAs. Seventy days after bioremediation, the concentration ranged from $56 \pm 2.3 \mu \mathrm{gg}^{-1}$ to $78 \pm 3.9 \mu \mathrm{g} \mathrm{g}^{-1}$ dry sediment. At different sampling sites, the removal rates ranged from $41 \%$ to $76 \%$ (concentration decreased from $273 \pm 13.7$ to $65 \pm 2.7 \mu \mathrm{g} \mathrm{g}^{-1}$ ), with an average removal rate of $54 \%$. On the whole, $n$-alkanes and PAHs in polluted sediments had similar degradation efficiencies. This result indicated that in situ bioremediation was an effective method for oil-spilled sediment remediation.

\section{Conclusions}

In situ bioremediation was performed by an eco-friendly and costeffective technology for oil polluted marine sediments. The zeolite with functional bacteria adsorbed and wrapped by $\gamma$-PGA could be used as an effective restored agent. The optimal conditions were below: GZ diameter was $3 \mathrm{~mm}$, mass ratio of GZ/PZ was 2:1 and concentration of $\gamma$ PGA was 7\%. After bioremediation, most oil spilled pollutants could be degraded over $50 \%$ with 70 days. In contrast to other common methods, in situ bioremediation is the preferred method for its lower cost, convenience, feasibility and sustainability. Due to its low operational cost requirements together with high degradable capacity for main oil spilled pollutants, this combined application is feasible in marine oil industry.

\section{Acknowledgments}

This study was supported by the National Natural Science Foundation of China (Grant No.: 41373100). Additional support was provided by Science and Technology Program for Public Wellbeing of Shandong Province (Grant No.: 2013kjhm060308) and CAS Key Technology Talent Program. We thank the North China Sea Branch of the State Oceanic Administration for their help by providing the wave

Table 4

Degradation rates of $n$-alkanes and PAHs in polluted sediments.

\begin{tabular}{|c|c|c|c|c|c|c|c|c|}
\hline \multirow{2}{*}{$\begin{array}{l}\text { Sampling sites } \\
\text { PHs }\end{array}$} & \multicolumn{2}{|l|}{$2 \#$} & \multicolumn{2}{|l|}{5 \# } & \multicolumn{2}{|l|}{$6 \#$} & \multicolumn{2}{|l|}{$11 \#$} \\
\hline & $n$-Alkanes & PAHs & $n$-Alkanes & PAHs & $n$-Alkanes & PAHs & $n$-Alkanes & PAHs \\
\hline Concentration (0 days) & $1776.9 \pm 71.1$ & $116.8 \pm 4.1$ & $3761.0 \pm 135.4$ & $151.7 \pm 6.1$ & $3681.8 \pm 128.9$ & $273.4 \pm 13.7$ & $2035.3 \pm 36.7$ & $102.9 \pm 2.1$ \\
\hline Concentration (70 days) & $1181.1 \pm 35.4$ & $56.4 \pm 2.3$ & $1393.1 \pm 55.8$ & $78.1 \pm 3.9$ & $1316.3 \pm 26.3$ & $65.5 \pm 2.7$ & $1086.9 \pm 21.7$ & $61.1 \pm 1.1$ \\
\hline Degradation (\%) & $33.53 \pm 2.1$ & $51.73 \pm 1.8$ & $62.96 \pm 2.4$ & $48.54 \pm 1.6$ & $64.25 \pm 4.9$ & $76.05 \pm 5.1$ & $46.61 \pm 1.7$ & $40.64 \pm 1.9$ \\
\hline
\end{tabular}


flume.

\section{References}

Brown, J.S., Stein, E.D., Ackerman, D., Dorsey, J.H., Lyon, J., Carter, P.M., 2013. Metals and bacteria partitioning to various size particles in Ballona creek storm water runoff. Environ. Toxicol. Chem. 32, 320-328(http://orcid.org/0000-0002-4729-809X).

Carriger, J.F., Barron, M.G., 2011. Minimizing risks from spilled oil to ecosystem services using influence diagrams: the deepwater horizon spill response. Environ. Sci. Technol. 45, 7631-7639. http://dx.doi.org/10.1021/es201037u.

Castaldi, P., Santona, L., Melis, P., 2005. Heavy metal immobilization by chemical amendments in a polluted soil and influence on white lupin growth. Chemosphere 60, 365-371. http://dx.doi.org/10.1016/j.chemosphere.2004.11.098.

Chettri, B., Mukherjee, A., Langpoklakpam, J.S., Chattopadhyay, D., Singh, A.K., 2016. Kinetics of nutrient enhanced crude oil degradation by Pseudomonas aeruginosa AKS1 and Bacillus sp. AKS2 isolated from Guwahati refinery, India. Environ. Pollut. 216, 548-558. http://dx.doi.org/10.1016/j.envpol.2016.06.008.

Dua, M., Singh, A., Sethunathan, N., Johri, A.K., 2002. Biotechnology and bioremediation: successes and limitations. Appl. Microbiol. Biotechnol. 59, 143-152. http://dx. doi.org/10.1007/s00253-002-1024-6.

Fernandez-Luqueno, F., Valenzuela-Encinas, C., Marsch, R., Martinez-Suarez, C., Vazquez-Nunez, E., Dendooven, L., 2011. Microbial communities to mitigate contamination of PAHs in soil-possibilities and challenges: a review. Environ. Sci. Pollut. Res. 18, 12-30. http://dx.doi.org/10.1007/s11356-010-0371-6.

Guo, J., Liu, X., Xie, Q., 2013. Characteristics of the Bohai Sea oil spill and its impact on the Bohai Sea ecosystem. Chin. Sci. Bull. 58, 2276-2281. http://dx.doi.org/10.1007/ s11434-012-5355-0.

Javed, I., Mateen, F., Rafique, U., Tabassum, N., Balkhair, K.S., Ashraf, M.A., 2016. Synthesis of zeolite from marble powder waste: a greener approach and its application for the removal of inorganic metals from wastewater. Desalin. Water Treat. 57, 10422-10431. http://dx.doi.org/10.1080/19443994.2015.1033763.

Kujawinski, E.B., Soule, M.C.K., Valentine, D.L., Boysen, A.K., Longnecker, K., Redmond, M.C., 2011. Fate of dispersants associated with the deepwater horizon oil spill. Environ. Sci. Technol. 45, 1298-1306. http://dx.doi.org/10.1021/es103838p.

Kumpiene, J., Lagerkvist, A., Maurice, C., 2008. Stabilization of As, $\mathrm{Cr}, \mathrm{Cu}, \mathrm{Pb}$ and $\mathrm{Zn}$ in soil using amendments - a review. Waste Manag. 28, 215-225. http://dx.doi.org/10. 1016/j.wasman.2006.12.012.

Lan, D., Liang, B., Bao, C., Ma, M., Xu, Y., Yu, C., 2015. Marine oil spill risk mapping for accidental pollution and its application in a coastal city. Mar. Pollut. Bull. 96 220-225. http://dx.doi.org/10.1016/j.marpolbul.2015.05.023.

Lei, Y.L., Li, T.G., Bi, H., Cui, W.L., Song, W.P., Li, J.Y., Li, C.C., 2015. Responses of benthic foraminifera to the 2011 oil spill in the Bohai Sea, PR China. Mar. Pollut. Bull. 96, 245-260. http://dx.doi.org/10.1016/j.marpolbul.2015.05.020.

Lim, M.W., Von Lau, E., Poh, P.E., 2016. A comprehensive guide of remediation technologies for oil contaminated soil - present works and future directions. Mar. Pollut. Bull. 109, 14-45. http://dx.doi.org/10.1016/j.marpolbul.2016.04.023.

Lin, P., Guo, L., 2015. Spatial and vertical variability of dissolved carbohydrate species in the northern Gulf of Mexico following the deepwater horizon oil spill, 2010-2011. Mar. Chem. 174, 13-25. http://dx.doi.org/10.1016/j.marchem.2015.04.001.

Liu, Y., Zou, C., Yan, X., Xiao, R., Wang, T., Li, M., 2015. $\beta$-Cyclodextrin modified natural chitosan as a green inhibitor for carbon steel in acid solutions. Ind. Eng. Chem. Res. 54, 5664-5672. http://dx.doi.org/10.1021/acs.iecr.5b00930.

Luo, Q., Zhang, J.-G., Shen, X.-R., Fan, Z.-Q., He, Y., Hou, D.-Y., 2013. Isolation and characterization of marine diesel oil-degrading Acinetobacter sp. strain Y2. Ann. Microbiol. 63, 633-640. http://dx.doi.org/10.1007/s13213-012-0513-9.

Matsusaki, M., Serizawa, T., Kishida, A., Endo, T., Akashi, M., 2002. Novel functional biodegradable polymer: synthesis and anticoagulant activity of poly(gamma-glutamic acid) sulfonate (gamma-PGA-sulfonate). Bioconjug. Chem. 13, 23-28(http://orcid. org/0000-0003-4294-9313).

Morales-Caselles, C., Riba, I., Sarasquete, C., DelValls, T.A., 2008. Using a classical weight-of-evidence approach for 4-years' monitoring of the impact of an accidental oil spill on sediment quality. Environ. Int. 34, 514-523. http://dx.doi.org/10.1016/j. envint.2007.11.007.

Nyankson, E., Demir, M., Gonen, M., Gupta, R.B., 2016. Interfacially active hydroxylated soybean lecithin dispersant for crude oil spill remediation. ACS Sustain. Chem. Eng. 4, 2056-2067. http://dx.doi.org/10.1021/acssuschemeng.5b01403.

Okoh, A.I., Trejo-Hernandez, M.R., 2006. Remediation of petroleum hydrocarbon polluted systems: exploiting the bioremediation strategies. Afr. J. Biotechnol. 5,
2520-2525(http://orcid.org/0000-0002-9770-085X).

Paola, S. De Velasco-Maldonado, Hernández-Montoya, Virginia, Montes-Morán, Miguel A., Vázquez, Norma Aurea-Rangel, Pérez-Cruzc, Ma. Ana, 2018. Surface modification of a natural zeolite by treatment with cold oxygen plasma: characterization and application in water treatment. Appl. Surf. Sci. 434, 1193-1199. http://dx.doi.org/ 10.1016/j.apsusc.2017.11.023.

Pavitran, S., Jagtap, C.B., Subramanian, S.B., Titus, S., Kumar, P., Deb, P.C., 2006. Microbial bioremediation of fuel oil hydrocarbons in marine environment. Def. Sci. J. 56, 209-224. http://dx.doi.org/10.14429/dsj.56.1884.

Peterson, C.H., 2001. The "Exxon Valdez" oil spill in Alaska: acute, indirect and chronic effects on the ecosystem. Adv. Mar. Biol. 39, 1-103. http://dx.doi.org/10.1016/ S0065-2881(01)39008-9.

Peterson, C.H., Rice, S.D., Short, J.W., Esler, D., Bodkin, J.L., Ballachey, B.E., Irons, D.B., 2003. Long-term ecosystem response to the Exxon Valdez oil spill. Science 302, 2082-2086. http://dx.doi.org/10.1126/science.1084282.

Petkewich, R., 2002. Spilled oil persists after 30 years. Environ. Sci. Technol. 36, 446A. http://dx.doi.org/10.1021/es022481n.

Ranjbar, P., Shafieefar, M., Rezvandoust, J., 2014. Modeling of oil spill and response in support of decreasing environmental oil effects case study: blowout from Khark subsea pipelines (Persian Gulf). Int. J. Environ. Res. 8, 289-296(http://orcid.org/ 0000-0003-3939-1670).

Schaum, J., Cohen, M., Perry, S., Artz, R., Draxler, R., Frithsen, J.B., Heist, D., Lorber, M., Phillips, L., 2010. Screening level assessment of risks due to dioxin emissions from burning oil from the BP deepwater horizon Gulf of Mexico spill. Environ. Sci. Technol. 44, 9383-9389. http://dx.doi.org/10.1021/es103559w.

Shi, W.-Y., Shao, H.-B., Li, H., Shao, M.-A., Du, S., 2009. Progress in the remediation of hazardous heavy metal-polluted soils by natural zeolite. J. Hazard. Mater. 170, 1-6. http://dx.doi.org/10.1016/j.jhazmat.2009.04.097.

Shi, S., Sadullah, M.S., Gondal, M.A., Sui, Y., Liu, S., Yamani, Z.H., Shen, K., Xu, Q., Mao, J., 2015. Wetting and non-wetting behavior of abrasive paper for oil water separation and oil spill clean up. Res. Chem. Intermed. 41 (11), 8019-8029. http://dx.doi.org/ 10.1007/s11164-014-1874-4.

Shi, D., Ran, M., Zhang, L., Huang, H., Li, X., Chen, M., Akashi, M., 2016. Fabrication of biobased polyelectrolyte capsules and their application for glucose-triggered insulin delivery. ACS Appl. Mater. Interfaces 8, 13688-13697. http://dx.doi.org/10.1021/ acsami.6b02121.

Song, J., Huang, S., Lu, Y., Bu, X., Mates, J.E., Ghosh, A., Ganguly, R., Carmalt, C.J., Parkin, I.P., Xu, W., Megaridis, C.M., 2014. Self-driven one-step oil removal from oil spill on water via selective-wettability steel mesh. ACS Appl. Mater. Interfaces 6, 19858-19865. http://dx.doi.org/10.1021/am505254j.

Suh, J.K.F., Matthew, H.W.T., 2000. Application of chitosan-based polysaccharide biomaterials in cartilage tissue engineering: a review. Biomaterials 21, 2589-2598. http://dx.doi.org/10.1016/S0142-9612(00)00126-5.

Tao, K., Liu, X., Chen, X., Hu, X., Cao, L., Yuan, X., 2017. Biodegradation of crude oil by a defined co-culture of indigenous bacterial consortium and exogenous Bacillus subtilis. Bioresour. Technol. 224, 327-332. http://dx.doi.org/10.1016/j.biortech.2016.10. 073.

Wang, X., Preston, J.F., Romeo, T., 2004. The pgaABCD locus of Escherichia coli promotes the synthesis of a polysaccharide adhesin required for biofilm formation. J. Bacteriol. 186, 2724-2734. http://dx.doi.org/10.1128/JB.186.9.2724-2734.2004.

Wang, S.-K., Wang, F., Hu, Y.-R., Stiles, A.R., Guo, C., Liu, C.-Z., 2014. Magnetic flocculant for high efficiency harvesting of microalgal cells. ACS Appl. Mater. Interfaces 6, 109-115. http://dx.doi.org/10.1021/am404764n.

Wang, X., Wang, X., Liu, M., Bu, Y., Zhang, J., Chen, J., Zhao, J., 2015. Adsorptionsynergic biodegradation of diesel oil in synthetic seawater by acclimated strains immobilized on multifunctional materials. Mar. Pollut. Bull. 92, 195-200. http://dx. doi.org/10.1016/j.marpolbul.2014.12.033.

Woolfrey, B.F., Enright, M.A., 1990. Ampicillin killing curve patterns for ampicillin-susceptible nontypeable Haemophilus influenzae strains by the agar dilution plate-count method. Antimicrob. Agents Chemother. 34, 1079-1087. http://dx.doi.org/10.1128/ AAC.34.6.1079.

Xu, E.G., Mager, E.M., Grosell, M., Pasparakis, C., Schlenker, L.S., Stieglitz, J.D., Benetti, D., Hazard, E.S., Courtney, S.M., Diamante, G., Freitas, J., Hardiman, G., Schlenk, D., 2016. Time- and oil-dependent transcriptomic and physiological responses to deepwater horizon oil in Mahi-Mahi (Coryphaena hippurus) embryos and larvae. Environ. Sci. Technol. 50, 7842-7851. http://dx.doi.org/10.1021/acs.est.6b02205.

Yavari, S., Malakahmad, A., Sapari, N.B., 2015. A review on phytoremediation of crude oil spills. Water Air Soil Pollut. 226, 226-279. http://dx.doi.org/10.1007/s11270015-2550-z. 